\title{
Pengaruh Brand Equity dan Product Knowledge Terhadap Minat Beli Konsumen Komunitas Hello Beauty Jakarta pada Produk \\ Wardah
}

\author{
Michelle Limartha dan Rezi Erdiansyah \\ Giselamichelle2@gmail.com,rexie@fikom.untar.ac.id \\ Fakultas Ilmu Komunikasi Universitas Tarumanagara
}

\begin{abstract}
This research was conducted to determine the Effect of Wardah Brand Equity and Product Knowledge on Buying Interest in the Hello Beauty Community in Jakarta. Because Wardah excelled in the assessment of Top Brand in Indonesia. The equity in the Wardah brand also creates a consumer repurchase intention for the brand. In addition, product knowledge is also important in developing brands and marketing. On the other hand, the hello beauty community is the first community in Indonesia and the largest in the field of beauty. The results of the analysis using the SPSS Ver.23 research method (Statistical Package for the Social Sciences) prove that brand equity and product knowledge simultaneously have an influence on Interests Buy in the Hellobeauty Jakarta community on Wardah products. In addition, there is the influence of brand equity influencing interests buy in the Hellobeauty Jakarta community on Wardah products and there is an influence of product knowledge on interest in buying in the Hellobeauty Jakarta community on Wardah Products.
\end{abstract}

Keywords: Brand Equity, Product Knowledge, Purchase Intention

\begin{abstract}
Abstrak
Penelitian ini dilakukan untuk mengetahui pengaruh Brand Equity dan Product Knowledge Wardah Terhadap Minat Beli di Komunitas Hello Beauty Jakarta. Berhubung Wardah unggul menurut penilaian Top Brand di Indonesia. Ekuitas dalam merek Wardah juga menimbulkan adanya niat pembelian kembali konsumen terhadap merek tersebut. Selain itu, pengetahuan produk menjadi hal penting juga dalam mengembangkan merek dan pemasaran. Di sisi lain, komunitas hello beauty merupakan komunitas pertama di Indonesia dan terbesar pada bidang kecantikan. Hasil analisis dengan metode penelitian SPSS Ver.23 (Statistical Package for the Social Sciences) membuktikan bahwa Brand Equity dan Product Knowledge secara bersamaan memiliki pengaruh terhadap minat beli di komunitas Hellobeauty Jakarta pada produk Wardah. Selain itu, terdapat pengaruh brand equity berpengaruh terhadap Minat Beli di komunitas Hellobeauty Jakarta pada produk Wardah serta terdapat pengaruh product knowledge terhadap Minat Beli di komunitas Hellobeauty Jakarta Pada Produk Wardah.
\end{abstract}

Kata kunci : Ekuitas merek, pengetahuan produk, minat beli

\section{Pendahuluan}

Merek merupakan elemen penting sebuah organisasi dalam pemasaran, Menurut Kotler dan Keller (2009: 258) merek adalah produk atau jasa yang dimensinya mendiferensiasikan merek tersebut dengan beberapa cara dari produk atau jasa lainnya yang dirancang untuk memuaskan kebutuhan yang sama.

Persaingan pada era ini telah berkonsentrasi pada sistem ekonomi Indonesia, dimana mekanisme pasar memposisikan diri sebuah perusahaan untuk merebut 
pangsa pasar. Cara untuk mencapai keadaan tersebut adalah mengembangkan merek dan produk pada pasar. Persaingan yang terjadi antar merek dan produk mendorong perusahaan untuk selalu melakukan pengembangan dan perbaikan untuk tetap meningkatkan minat beli konsumen.

Untuk menjaga penampilan manusia, maka diperlukan penampilan yang menarik. Maka dari itu menjadi sebuah alasan utama setiap perusahaan di bidang kecantikan berusaha untuk menarik minat beli konsumen.

Merek yang berkualitas memiliki empat dimensi yang penting yaitu, citra merek, kesadaran merek, loyalitas merek, asosiasi merek dan persepsi kualitas. Ekuitas merek juga bisa dijadikan variabel pengukur minat beli konsumen. Product knowledge memiliki peran penting dalam proses pengambilan keputusan merek mana yang mereka akan gunakan

Berdasarkan uraian diatas, peneliti akan melakukan penelitian untuk menganalisa adakah pengaruh brand equity dan product knowledge Wardah terhadap minat beli konsumen di komunitas Hello Beauty Jakarta dengan judul: Pengaruh Brand Equity Dan Product Knowledge Terhadap Minat Beli Konsumen Komunitas Hello Beauty Jakarta Pada Produk Wardah.

Kerangka teoritis, Konsep merek: Menurut Kotler (2009:332), merek adalah nama, istilah, simbol atau rancangan, atau kombinasi hal-hal tersebut yang dimaksud konsumen untuk mengidentifikasi barang atau jasa dari seseorang atau kelompok penjual dan untuk membedakannya dari pesaing. Merek-merek yang kuat akan memberikan jaminan kualitas dan nilai yang tinggi kepada pelanggan, yang akhirnya juga akan berdampak luas terhadap perusahaan.

Ekuitas Merek (Brand Equity): Ekuitas merek adalah seperangkat asosiasi dan perilaku yang dimiliki oleh pelanggan merek, anggota saluran distribusi, dan perusahaan yang memungkinkan suatu merek mendapatkan kekuatan, daya tahan, dan keunggulan yang membedakan dengan para pesaing (David A Aaker, 2013:204). Menurut David A. Aaker (2013:57) ekuitas merek ditentukan oleh empat dimensi atau elemen utama yaitu brand awareness, brand associations, perceived quality, brand loyalty. Kesadaran merek (brand awareness) adalah kemampuan pelanggan untuk mengenali dan mengingat kembali sebuah merek dan mengaitkannya dengan suatu produk tertentu. Kesadaran merek melibatkan pengakuan merek dan ingatan tentang merek. Persepsi kualitas (perceived quality) terhadap merek menggambarkan respon keseluruhan pelanggan terhadap kualitas dan keunggulan yang ditawarkan merek. Loyalitas merek (brand loyalty) adalah komitmen kuat dalam berlangganan atau membeli kembali suatu merek secara konsisten di masa mendatang.

Product knowledge: Menurut Peter dan Olson (2010: 70-75), terdapat empat indikator dalam produk knowledge, yaitu atribut produk, manfaat fungsional, manfaat psikologis, dan nilai-nilai yang diperoleh apabila konsumen mengkonsumsi produk atau jasa.

Product Knowledge dibagi kedalam 3 kategori, yaitu:

a. Subjective knowledge / Perceived knowledge, merujuk kepada seberapa banyak responden tahu mengenai suatu produk;

b. Objective knowledge, Seberapa banyak informasi dan jenis informasi yang terdapat dalam memori konsumen;

c. Experience based knowledge, Seberapa banyak pengalaman konsumen dalam pembelian dan pemakaian suatu produk. Faktor ini bersifat tidak konsisten dengan proses pemrosesan informasi. Hal ini dapat dilihat ketika pengalaman hanya mempengaruhi perilaku ketika perilaku tersebut menghasilkan perbedaan di dalam 
memori konsumen. Jika konsumen yang berbeda belajar hal yang berbeda dari pengalaman yang sama maka perilaku mereka juga akan berbeda.

Minat Beli: Menurut Kotler dan Keller (2009 : 398) minat beli adalah sebuah perilaku konsumen dimana konsumen mempunyai keinginan untuk membeli atau memilih suatu produk berdasarkan pengalaman dalam memilih, menggunakan, dan mengkonsumsi atau bahkan menginginkan suatu produk.

Menurut Ferdinand (2006:129), minat beli dapat diidentifikasi melalui indikator-indikator sebagai berikut:

1. Minat transaksional, yaitu kecenderungan seseorang untuk membeli produk.

2. Minat referensial, yaitu kecenderungan seseorang untuk mereferensasikan produk kepada orang lain.

3. Minat preferensial, yaitu minat yang menggambarkan perilaku seseorang yang memiliki prefrensi utama pada produk tersebut. preferensi ini hanya dapat diganti jika terjadi sesuatu dengan produk preferensinya.

4. Minat eksploratif, yaitu minat yang menggambarkan perilaku seseorang yang selalu mencari informasi mengenai produk yang diminatinya dan mencari informasi untuk mendukung sifat-sifat positif dari produk tersebut. Kerangka Pemikiran:

\section{Gambar 1 Kerangka Pemikiran}

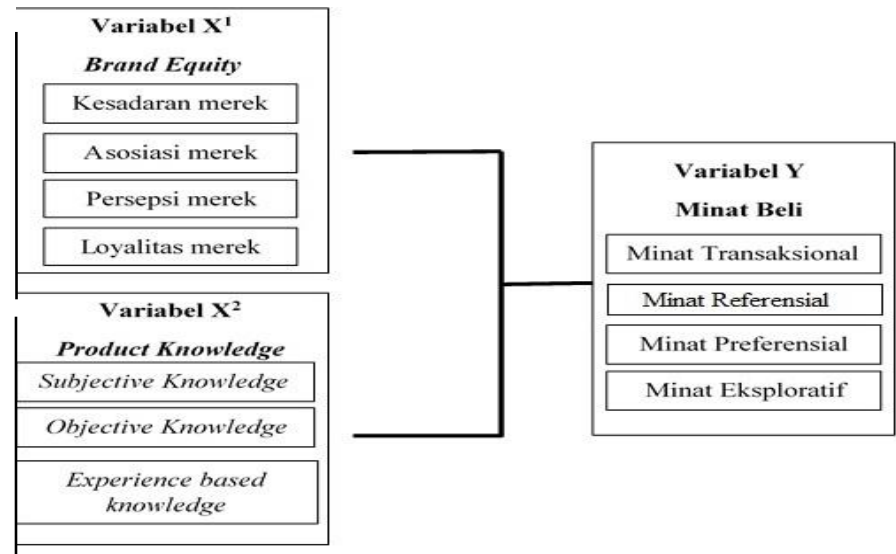

Sumber : Data Peneliti

\section{Metode Penelitian}

Metode penelitian yang digunakan adalah metode kuantitatif. Dengan jenis penelitian survei. Data dikumpulkan dengan penyebaran kuesioner menggunakan skala likert. Penelitian ini bersifat survey eksplanatif. Pada penelitian ini, teknik yang digunakan peneliti untuk pengambilan sampel adalah Non probability sampling dengan teknik penarikan sampel purposive sampling. Sampel dalam penelitian ini adalah 108 anggota komunitas Hello Beauty Jakarta. Data dalam penelitian ini diperoleh melalui kuisioner, studi kepustakaan dan skala pengukuran.

Keabsahan data yang digunakan yaitu uji validitas, uji reliabilitas dan uji normalitas. Untuk pengolahan data dalam penelitian ini, peneliti menggunakan uji F, uji $\mathrm{T}$, uji regresi linear berganda, uji koefisien korelasi berganda, dan uji koefisien determinasi. Berikut merupakan hipotesis penelitian ini :

$\mathrm{H}_{\mathrm{a} 1}$ : Terdapat pengaruh brand equity berpengaruh terhadap Minat Beli komunitas Hellobeauty Jakarta pada produk Wardah. 
$\mathrm{H}_{\mathrm{o} 1}$ : Tidak terdapat pengaruh brand equity terhadap minat beli komunitas Hellobeauty Jakarta pada produk Wardah.

$\mathrm{H}_{\mathrm{a} 2}$ : Terdapat pengaruh product knowledge terhadap minat beli komunitas Hellobeauty Jakarta pada produk Wardah.

$\mathrm{H}_{\mathrm{o} 2}$ : Tidak terdapat pengaruh product knowledge terhadap minat beli komunitas Hellobeauty Jakarta pada produk Wardah.

$\mathrm{H}_{\mathrm{a} 3}$ : Terdapat pengaruh brand equity dan product knowledge secara bersamaan terhadap minat beli komunitas Hellobeauty Jakarta pada produk Wardah.

$\mathrm{H}_{03}$ : Tidak terdapat pengaruh brand equity dan product knowledge secara bersamaan terhadap minat beli komunitas Hellobeauty Jakarta pada produk Wardah.

\section{Hasil Temuan dan Diskusi}

Uji Validitas

Dalam penelitian ini, peneliti menyebarkan kuisioner kepada 108 responden dengan 22 pertanyaan yang diuji. Hasil yang peneliti peroleh dinyatakan valid karena $\mathrm{r}$ hitung lebih besar dari $\mathrm{r}$ tabel. Karena nilai dari corrected item total correlation lebih besar dari nilai patokannya, yaitu 0,200.

Uji Reliabilitas, Uji Reliabilitas X1 (Brand Equity):

Peneliti mendapatkan hasil 0,849 untuk pernyataan X1 (Brand Equity) menggunakan SPSS Ver.23 . Pernyataan tersebut dinyatakan reliabel karena $\mathrm{r}$ hitung > r tabel yaitu $0,849>0,70$.

Uji Reliabilitas X2 (Product Knowledge):

Peneliti mendapatkan hasil 0,823 untuk pernyataan X1 (Product Knowledge) menggunakan SPSS Ver.23 . Pernyataan tersebut dinyatakan reliabel karena $r$ hitung $>r$ tabel yaitu $0,823>0,70$.

Uji Reliabilitas Y (Minat Beli):

Peneliti mendapatkan hasil 0,926 untuk pernyataan $\mathrm{Y}$ (Minat Beli) menggunakan SPSS Ver.23 . Pernyataan tersebut dinyatakan reliabel karena $\mathrm{r}$ hitung $>r$ tabel yaitu $0,926>0,70$.

Uji Normalitas

Terlihat dari penyebaran data (titik) pada sumbu diagonal. Maka dengan bantuan SPSS 23 peneliti mendapatkan hasil distrubusi normal dengan sumbu diagonal.

\section{Uji T}

Variabel X1 (Brand Equity) : Berdasarkan hasil uji T , maka nilai T tabel X1 adalah 1,982 dan nilai $\mathrm{T}$ hitung adalah 2,298. Dapat simpulkan bahwa $\mathrm{T}$ hitung $>\mathrm{T}$ tabel dan sig > a yaitu, 4,376 > 1,982 dan 0,024<0,05 maka Ha diterima dan Ho ditolak. Maka terdapat pengaruh Brand Equity berpengaruh terhadap Minat Beli di komunitas Hello Beauty Jakarta.

Variabel X2 (Product Knowledge): Berdasarkan hasil uji T, maka nilai T tabel $\mathrm{X} 2$ adalah 1,982 dan nilai $\mathrm{T}$ hitung adalah 12,703. Dapat simpulkan bahwa $\mathrm{T}$ hitung > $\mathrm{T}$ tabel dan sig > a yaitu, 12,703 > 1,982 dan 0,000 < 0,05 maka Ha 
diterima dan Ho ditolak. Maka terdapat pengaruh Product Knowledge terhadap Minat Beli di komunitas Hello Beauty Jakarta.

\section{Uji F}

Berdasarkan hasil analisis, nilai $F_{\text {tabel }}$ adalah 3,08 dan nilai $F_{\text {hitung }}$ adalah 177.854 maka $F_{\text {hitung }}>F_{\text {tabel }}$ yaitu $177.854>3,09$, serta nilai sig $<0,05$ yaitu $0,000<0,05$. Hal ini dapat dikatakan hasil uji $\mathrm{F}$ adalah Ha diterima dan Ho ditolak, artinya Terdapat pengaruh Brand Equity dan Product Knowledge secara bersamaan terhadap Minat Beli di komunitas Hello Beauty Jakarta.

\section{Uji Regresi Linear Berganda}

Berdasarkan hasil uji, maka dapat dirumuskan persamaan regresi liner berganda, persamaan tersebut adalah :

$Y=-1,083+0,181 X 1+1.115 X 2$

Penjelasan dari persamaan diatas adalah sebagai berikut :

Setiap ada penambahan 1 angka atau perubahan variabel X1 (brand equity), maka variabel Y (minat beli) akan mengalami peningkatan sebesar 0,181. Setiap ada penambahan 1 angka atau perubahan variabel X2 (product knowledge), maka variabel Y (minat beli) akan mengalami peningkatan sebesar 1,115.

\section{Uji Koefisien Determinasi}

Berdasarkan hasil analisis, diketahui hasil koefisien determinasi dengan melihat angka yang ada pada R Square. Hasil dari R Square adalah 0,772, maka dapat dikatakan bahwa kemampuan variabel-variabel X1 (Brand Equity) dan X2 (Product Knowledge) dalam memperngaruhi variabel Y (Minat Beli) cukup kuat karena nilai koefisien determinasi tidak mendekati angka 1. Berdasarkan hasil uji koefisien determinasi pada tabel 4.33, dapat dikatakan bahwa Minat beli Wardah dipengaruhi sebesar 77,2\% oleh Brand Equity dan Product Knowledge, sementara sisa $27,8 \%$ dipengaruhi oleh variabel-variabel lain.

\section{Uji Korelasi Berganda}

Berdasarkan hasil analisis, diketahui bahwa hasil uji koefisien korelasi berganda dari variabel X1 (Brand Equity) dan X2 (Product Knowledge) terhadap variabel Y (Minat Beli) dalam penelitian ini sebesar 0,879. Menurut Sugiyono (2017:231) pada tabel 3.3 di Bab III, jika hasil interval koefisien sebesar 0,80-1,000 maka tingkat hubungan antar variabel dinyatakan sangat kuat. Maka dapat dikatakan bahwa hubungan antara variabel $\mathrm{X} 1$ dan $\mathrm{X} 2$ terhadap $\mathrm{Y}$ dalam penelitian ini adalah sangat kuat.

Penelitian ini dilakukan dengan menggunakan metode kuantitatif, pengumpulan data menggunakan kuisioner. Dalam penelitian ini, peneliti mengambil sampel sebanyak 108 orang dengan pengolahan data menggunakan SPSS versi 23.

Dari 108 responden, dapat disimpulkan bahwa jumlah responden perempuan lebih banyak dibandingkan jumlah responden laki-laki yaitu sebesar 101 orang. Berdasarkan analisis melalui usia, terdapat 10 responden $(9,3 \%)$ berusia dibawah 20 tahun, 57 responden ( 52,8 \% ) berusia 21-25 tahun, 29 responden $(26,9 \%)$ berusia 26-30 tahun, 12 responden $(11,1 \%)$ berusia diatas 30 tahun. Berdasarkan analisis dari segi Pendidikan terakhir responden, dari 108 responden terdapat 0 responden (0\%) yang memiliki Pendidikan terakhir TK, 0 responden ( $0 \%$ ) yang memiliki Pendidikan terakhir SD, 2 responden $(1,9 \%$ ) yang memiliki Pendidikan terakhir 
SMP, 45 responden $(41,7 \%)$ yang memiliki Pendidikan terakhir SMA, 10 responden (9,3\%) yang memiliki Pendidikan terakhir D3/Sederajat, 50 responden $(46,3 \%)$ yang memiliki Pendidikan terakhir S1, 1 responden $(0,9 \%)$ yang memiliki Pendidikan terakhir S2, 0 responden (0\%) yang memiliki Pendidikan terakhir S3.

Pada penelitian ini terdapat 3 variabel, yaitu variabel Brand Equity (X1) dan variabel Product Knowledge (X2) sebagai variabel independent (bebas), serta variabel Minat Beli (Y) sebagai variabel dependent (terikat). Penelitian ini dibuat dengan tujuan untuk mengetahui seberapa besar pengaruh dari brand equity dan product knowledge terhadap minat beli konsumen komunitas Hello Beauty pada produk Wardah. Variabel X1 (brand equity) memiliki 4 dimensi yaitu kesadaran merek, asosiasi merek, persepsi merek dan loyalitas merek. Variabel X2 (product knowledge) memiliki 3 dimensi yaitu subjective knowledge, objective knowledge dan experience based knowledge. Variabel Y (minat beli) memiliki 4 dimensi yaitu minat transaksional, minat referensial, minat preferensial, dan minat eksploratif.

Berdasarkan hasil yang diperoleh dari program perhitungan SPSS, dapat disimpulkan bahwa hasil uji validitas dari setiap pernyataan yang berada dalam kuisioner dinyatakan valid, karena item-item pernyataan yang dalam kuisioner data digunakan untuk mengukur pengaruh minat beli pada brand Wardah di komunitas Hello Beauty terkhususnya. Selain itu, hasil uji reliabilitas menyatakan bahwa ketiga variabel dalam penelitian ini reliabel. Berarti kuisioner yang dibuat dalam penelitian ini dapat digunakan dan dibagikan lebih dari satu kali. Uji normalitas yang digunakan untuk menguji apakah variable terikat, variable bebas, atau bahkan keduanya memiliki distribusi normal atau tidak dari model regresinya. Model regresi yang baik memiliki distribusi data yang normal pula. Terlihat dari penyebaran data (titik) pada sumbu diagonal. Maka dengan bantuan SPSS 23 peneliti mendapatkan hasil distribusi normal dengan sumbu diagonal.

Hasil dari nilai koefisien korelasi berganda dalam penelitian ini adalah sebesar 0,879 yang artinya hubungan antara ketiga variabel ini termasuk ke dalam kategori sangat kuat, berdasarkan yang disampaikan oleh Sugiyono (2017:231) yang menyatakan jika hasil interval koefisien sebesar 0,60-0,799 maka tingkat hubungan antar variabel dinyatakan sangat kuat.

Hasil koefisien determinasi dalam penelitian ini sebesar 0,772 dapat dikatakan bahwa sebesar dipengaruhi sebesar 77,2\% oleh Brand Equity dan Product Knowledge, sementara sisa 27,8\% dipengaruhi oleh variabel-variabel lain.

Hasil dari uji regresi linier berganda terdapat persamaan: $\mathrm{Y}=-1,083+$ 0,181X1 + 1.115X2. Dari persamaan ini, dapat diartikan bahwa Setiap ada penambahan 1 angka atau perubahan variabel X1 (brand equity), maka variabel $\mathrm{Y}$ (minat beli) akan mengalami peningkatan sebesar 0,181 . Setiap ada penambahan 1 angka atau perubahan variabel X2 (product knowledge), maka variabel Y (minat beli) akan mengalami peningkatan sebesar 1,115 . Untuk menunjukkan pengaruh masingmasing variabel brand equity dan product knowledge terhadap minat beli digunakan uji T. Pada hasil uji T dari variabel brand equity, nilai t hitung adalah sebesar 4,376 maka $\mathrm{t}$ hitung $\leq \mathrm{t}$ tabel yaitu 4,376 $\leq 1,982$, artinya terdapat pengaruh brand equity terhadap minat beli. Selanjutnya pada hasil uji T dari variabel product knowledge, nilai $\mathrm{t}$ hitung adalah sebesar 12,703, maka $\mathrm{t}$ hitung $\geq \mathrm{t}$ tabel yaitu $12,703 \geq 1,988$, artinya terdapat pengaruh signifikan product knowledge terhadap minat beli. Maka, dapat dikatakan bahwa brand equity memiliki pengaruh terhadap minat beli. Sedangkan, product knowledge memiliki pengaruh terhadap minat beli. Hasil dari uji $\mathrm{F}$ adalah nilai $\mathrm{F}$ hitung sebesar 177.854 maka $\mathrm{F}$ hitung $>\mathrm{F}$ tabel yaitu $177.854>$ 3,09. 
Maka, dapat dikatakan bahwa terdapat pengaruh brand equity dan product knowledge secara bersama-sama terhadap minat beli.

Berdasarkan hasil analisis dan pembahasan di atas, tidak terdapat perbedaan di antara kedua variabel dependen dalam mempengaruhi variabel terikat. Secara parsial, brand equity memiliki pengaruh yang signifikan terhadap minat beli, sedangkan product knowledge memiliki pengaruh yang signifikan terhadap minat beli. Dan secara simultan atau bersamaan, brand equity dan product knowledge memiliki pengaruh terhadap minat beli.

\section{Simpulan}

1. Berdasarkan hasil analisis diatas, nilai $F_{\text {tabel }}$ adalah 3,08 dan nilai $F_{\text {hitung }}$ adalah 177.854 maka $F_{\text {hitung }}>F_{\text {tabel }}$ yaitu $177.854>3,08$, serta nilai sig $<0,05$ yaitu $0,000<0,05$. Hal ini dapat dikatakan hasil uji $\mathrm{F}$ adalah Ha diterima dan Ho ditolak, artinya Terdapat pengaruh Brand Equity dan Product Knowledge secara bersamaan terhadap Minat Beli komunitas Hellobeauty Jakarta pada produk Wardah.

2. Berdasarkan hasil uji T, T tabel X1 dan X2 adalah 1,982. Nilai T hitung X1 adalah 2,298 dan nilai T hitung X2 adalah 12,703. Dapat simpulkan bahwa T hitung $>$ T tabel dan sig > a yaitu, 4,376 > 1,982 dan 0,024<0,05 pada X1, dan pada X2 yaitu, 12,703 > 1,982 dan 0,000 < 0,05 maka kedua Ha diterima dan Ho ditolak, artinya terdapat pengaruh Brand Equity berpengaruh terhadap Minat Beli dan terdapat pengaruh Product Knowledge terhadap Minat Beli komunitas Hellobeauty Jakarta pada produk Wardah.

3. Berdasarkan hasil uji koefisien determinasi di atas, dapat dikatakan bahwa Minat beli Wardah dipengaruhi sebesar 77,2\% oleh Brand Equity dan Product Knowledge di komunitas Hello Beauty Jakarta, sementara sisa 27,8\% dipengaruhi oleh variabel-variabel lain.

\section{Ucapan Terimakasih}

Ucapan terimakasih ditunjukan kepada dosen pembimbing bapak Rezi Erdiansyah, Dr.,M.Si yang telah banyak membantu dan membimbing selama proses penelitian ini berlangsung samapi dengan pembuatan artikel jurnal ini.

Saran: Pihak perusahaan wardah dapat memanfaatkan temuan penelitian ini untuk menggali dan mempelajari setiap faktor yang dapat berdampak positif terhadap minat beli konsumen komunitas Hello Beauty Jakarta selain brand equity dan product knowledge. Perusahaan tetap mempertahankan brand equity dan memberikan product knowledge terhadap konsumen secara tepat dan efektif agar minat beli konsumen tetap terjaga atau meningkat. Untuk penelitian selanjutnya dengan tema yang serupa, diharapkan dapat mengembangkan penelitian tentang brand equity, product knowledge dan minat beli Wardah dengan menggunakan paradigma, dan teknik penelitian dari perspektif lain. Kemudian untuk peneliti lain, diharapkan dapat melihat kondisi pada saat ingin menyebarkan kuisioner dan memilih responden yang tepat sesuai dengan tujuan penelitian. 


\section{Daftar Pustaka}

Aaker, David A. (2013). Manajemen Pemasaran Strategi. Edisi kedelapan. Jakarta : Salemba Empat.

Ferdinand, Augusty, Prof. (2006). Metode Penelitian Manajemen. Semarang: Badan Penerbit Universitas Diponegoro.

Kotler dan Keller. (2009). Manajemen Pemasaran. Jilid 1. Edisi ke 13. Jakarta : Erlangga.

Lin, Nan Hong and B.S Lin. (2007). The Effect of Brand Image and Product Knowledge on Purchase Intention Moderated by Price Discount. Journal of International Management Studies. Vol. 2, No. 13, 121-132.

Peter J. Paul dan Olson Jerry C. (2010). Consumer behavior and Marketing Strategy 9th ed. New York. USA : Mc. Graw Hill.

Sugiyono. (2013). Metodelogi Penelitian Kuantitatif, Kualitatif Dan R\&D. Bandung: Alfabeta. 